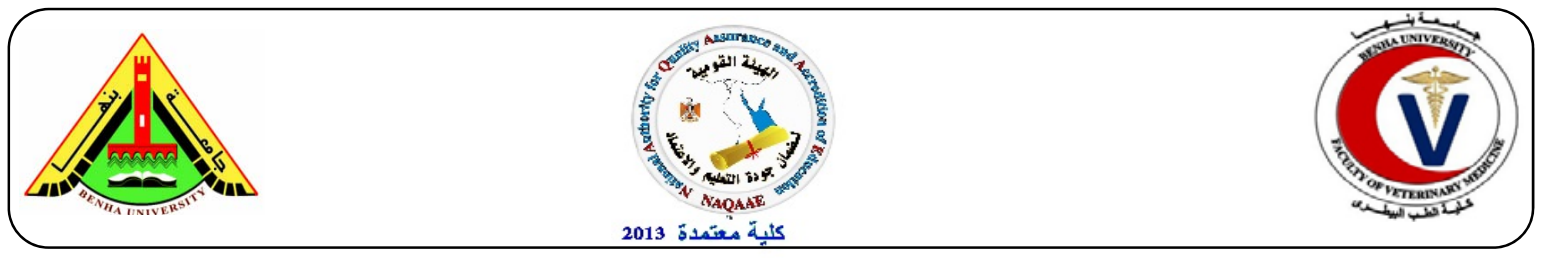

\title{
Biogenic amines residues in canned fish
}

Fahim, A. Shaltout ${ }^{\mathbf{1}}$, Amani M. Salem ${ }^{\mathbf{1}}$, Mohamed, F. Hashim ${ }^{\mathbf{2}}$ and Amal A. Farag ${ }^{\mathbf{1}}$

${ }^{1}$ Food Control Department, Fac. Vet. Med., Benha University. ${ }^{2}$ Food Hygiene, Animal Health Research Institute, Dokki, Giza.

\section{A B S T R A C T}

One hundred random samples of local and imported canned Tuna and Mackerel fish ( 25 of each) were analyzed for detection and determination of biogenic amines residues (histamine, tyramine and putrescine) by High Performance Liquid Chromatography (HPLC). The obtained results revealed that the average concentration levels of histamine, tyramine, and putrescine $(\mathrm{mg} / \mathrm{kg})$ were $22.86 \pm 0.72$, $0.274 \pm 0.035 \& 1.884 \pm 0.181,19.48 \pm 0.64,0.184 \pm 0.177 \& 1.72 \pm 0.076,36.72 \pm 1.807,0.393 \pm 0.048 \&$ $2.1 \pm 0.104,29.04 \pm 1.46,0.368 \pm 0.047$ and $1.894 \pm 0.115$ for local and imported tuna and mackerel samples, respectively. All Samples of both canned tuna and mackerel were acceptable for histamine, tyramine and putrescine Except $8 \%$ of local canned mackerel A exceeded permissible limits for histamine according to Egyptian Organization of Standardization (EOS, 2005).

Keywords: Biogenic amines, canned tuna, canned mackerel, Histamine, Tyramine

$$
\text { (http://www.bvmj.bu.edu.eg) }
$$

(BVMJ-29(1): 164-169, 2015)

\section{INTRODUCTION:}

$\mathrm{B}$ iogenic amines are nitrogenous low molecular mass organic bases found in variety of foods (Lorenzo, 2007). The most important biogenic amines in canned fish are histamine, tyramine and putrescine, which are formed by the enzymatic decarboxylation of histidine, tyrosine, and ornithine, respectively (Silva, 2011). Histamine producing bacteria were Escherichia, Klebsiella, Salmonella, Shigella, Proteus, Citrobacter, Enterobacter, Serratia, Hafnia, Clostridia Perferingens, Bacillus cerrus, Pseudomonas aeruginosa, Strept. Fecalis and Strept. faecium (Byran, 1980). Biogenic amines are considered as precursors of carcinogens, such as $\mathrm{N}$ nitrosamines (Andreson, 2008). Histamine in high levels produce scombroid fish poisoning which characterized by tingling, burning sensation of the mouth, urticaria, flushing, vomiting and diarrhea (Taylor, 1986). Putrescine potentiate histamine toxicity (Tsai, 2005). High concentrations of tyramine in food lead to a hypertension crisis known as "cheese reaction" (Hannah et al., 1988). Considering all these hazards, the current study was applied to monitor some biogenic amines (histamine, tyramine and putrescine) in canned fish (Tuna and Mackerel) in Egypt.

\section{MATERIALS AND METHODS}

\subsection{Collection of samples:}

A total of 100 random of samples of local and imported canned Tuna and Mackerel ( 25 of each) were collected from different hygienic level supermarkets in Cairo and Menofia governorates and transferred to the laboratory in Animal Health Research Institute Dokki branch for detection and determination of their biogenic amines (histamine, tyramine and putrescine).

\subsection{Determination of biogenic amines :}


It is carried out by using High Performance Liquid Chromatography (HPLC) according to Mietz and Karmas (1977).

\subsubsection{Amine extraction :}

$25 \mathrm{~g}$ of canned fish samples were homogenized with $125 \mathrm{ml}$ of $5 \%$ Trichloroacetic acid TCA for $3 \mathrm{~min}$. using warning blender. Then filtration was achieved using Whatman No(1) filter paper and $10 \mathrm{ml}$ of the filtrate were transferred into glass tube with $4 \mathrm{~g} \mathrm{NaCl}$ and $1 \mathrm{ml}$ of $50 \% \mathrm{NaOH}$ then shacked and extracted 3 times by $5 \mathrm{ml} \mathrm{n}$-butanol: chloroform (1:1 $\mathrm{v} / \mathrm{v}$ ) stoppered and shacked vigorously for 2 min. followed by centrifugation for $5 \mathrm{~min}$. at $3000 \mathrm{rpm}$. The upper layer was transferred to $50 \mathrm{ml}$ separating funnel using disposable Pasteur pipette. To the combined organic extracts (upper layer), $15 \mathrm{ml}$ of $\mathrm{n}$ heptane was added and extracted 3 times with $1.0 \mathrm{ml}$ portions of $0.2 \mathrm{n}-\mathrm{HCL}$ then $\mathrm{n}$ HCL layer was collected in a glass stoppered tube. Solution was evaporated just to dryness using water bath at $95^{\circ} \mathrm{c}$ with the aid of air currents.

\subsubsection{Formation of Dansyl amines:}

$100 \mu 1$ of each stock standard solution was transferred to a vial $(50 \mathrm{ml})$ and dried under vacuum. About $0.5 \mathrm{ml}$ of saturated $\mathrm{NaHCO}_{3}$ solution was added to the residue of the sample extract (or the standard), vial was stoppered and its content was carefully mixed to prevent loss due to spattering. Carefully, $1.0 \mathrm{ml}$ dansyl chloride solution was added and mixed thoroughly using Vortex Mixer. The reaction mixture was incubated at $55^{\circ}$ for $45 \mathrm{~min}$. then $10 \mathrm{ml}$ of distilled water was added to the reaction mixture and the vial was stoppered and shacked vigorously using Vortex Mixer. The extraction of dansylated biogenic amines was carried out using $5 \mathrm{ml}$ diethyl ether for 3 times. Again, the vial was stoppered then shacked carefully for $1 \mathrm{~min}$. and the ether layers were collected in culture tube using disposable Pasteur pipette. The combined ether extracts were carefully evaporated at $35^{\circ} \mathrm{c}$ in dry bath with the aid of air current. The obtained dry film was dissolved in $1 \mathrm{ml}$ methanol, and then $10 \mu$ was injected in HPLC.

\subsection{Statistical analysis}

Data were statistically analyzed using Pearson Correlation test significant at $P$ $<0.05$ (SPSS 14, 2006).

\section{RESULTS}

Results achieved in Table (1) revealed that the mean values of histamine levels $(\mathrm{mg} / \mathrm{kg})$ were $22.86 \pm 0.72,25.3 \pm 0.603 \& 19.2 \pm 0.448$ in all local tuna, local tuna $\mathrm{A}$ and local tuna B samples, respectively. Also, $19.48 \pm 0.64$, $21.6 \pm 0.468 \& 16.3 \pm 0.601$ in all imported tuna, imported tuna $\mathrm{A}$ and imported tuna $\mathrm{B}$ samples, respectively. In addition, the histamine means for all local mackerel, local mackerel A and local mackerel B were $36.72 \pm 1.807,42.33 \pm 1.75 \& 27.8 \pm 0.711$ in all local mackerel, local mackerel $\mathrm{A}$ and local mackerel B samples, respectively. Further, $29.04 \pm 1.46, \quad 33.066 \pm 1.75$ and $23 \pm 0.63$ in all imported mackerel, imported mackerel A and imported mackerel B samples, respectively. Means of different groups within the same column having different superscripts are significantly different $(P \leq 0.05)$. On the other hand, the results in Table (2) illustrated that the mean values of tyramine in all local tuna, local tuna $\mathrm{A}$ and local tuna $\mathrm{B}$ samples were $0.274 \pm 0.035, \quad 0.36 \pm 0.040 \quad \& \quad 0.141 \pm 0.38$, respectively. In all imported tuna, imported tuna $\mathrm{A}$ and imported tuna B samples $0.184 \pm 0.177,0.242 \pm 0.016 \& 0.099 \pm 0.009$, respectively. Moreover, its means for all local mackerel, mackerel $\mathrm{A}$ and local mackerel B samples, they were $0.393 \pm 0.0485, \quad 0.556 \pm 0.040 \quad \&$ $0.174 \pm 0.015, \quad$ respectively. Also, $0.368 \pm 0.047,0.497 \pm 0.058$ and $0.148 \pm 0.026$ in all imported mackerel, imported mackerel and imported mackerel B samples, respectively. Means of different groups within the same column having 
different superscripts are significantly different $(P \leq 0.05)$. Consequently, the results in Table (3) reported that the mean values of putrescine were $1.884 \pm 0.181$, $2.20 \pm 0.119 \& 1.41 \pm 0.057$ in all local tuna, local tuna A and local tuna B samples, respectively. Also, 1.72 $\pm 0.076,1.96 \pm 0.68$ \& $1.36 \pm 0.067$ in all imported tuna, imported tuna A and imported tuna B samples, respectively. In addition, its means for all local mackerel, local mackerel A and local mackerel B samples 2.1 \pm 0.104 , $2.4 \pm 0.119 \& 1.65 \pm 0.0453$, respectively. Also, $\quad 1.894 \pm 0.115, \quad 2.237 \pm 0.126$ and
$1.38 \pm 0.0553$ in all imported mackerel, imported mackerel $\mathrm{A}$ and imported mackerel B samples, respectively. Means of different groups within the same column having different superscripts are significantly different $(P \leq 0.05)$. At the same time, the results in Table 4 revealed that all Tuna and Mackerel samples are within the permissible limits for histamine, tyramine and putrescine according to (EOS, 2005 ) except $8 \%$ of local canned mackerel A exceeded permissible limits for histamine.

Table (1): Mean values of histamine levels in the examined samples of canned fish $(\mathrm{mg} / \mathrm{kg})$

\begin{tabular}{|c|c|c|c|c|c|c|c|}
\hline \multirow{2}{*}{ Product } & \multirow{2}{*}{ No } & \multicolumn{3}{|c|}{ Tuna } & \multicolumn{3}{|c|}{ mackerel } \\
\hline & & Min & $\max$ & $\operatorname{Mean} \pm \mathrm{SE}^{*}$ & Min & $\max$ & $\operatorname{Mean} \pm \mathrm{SE}^{*}$ \\
\hline Local A & 15 & 22 & 30 & $25.3 \pm 0.603$ & 34 & 52 & $42.33 \pm 1.75$ \\
\hline Local B & 10 & 17 & 21 & $19.2 \pm 0.448$ & 25 & 31 & $27.8 \pm 0.711$ \\
\hline Total & 25 & 17 & 30 & $22.86 \pm 0.72$ & 25 & 52 & $36.72 \pm 1.807$ \\
\hline Imported A & 15 & 19 & 25 & $21.6 \pm 0.468$ & 25 & 45 & $33.066 \pm 1.75$ \\
\hline Imported B & 10 & 12 & 18 & $16.3 \pm 0.601$ & 20 & 25 & $23 \pm 0.63$ \\
\hline Total & 25 & 12 & 25 & $19.48 \pm 0.64$ & 20 & 45 & $29.04 \pm 1.46$ \\
\hline
\end{tabular}

*Means of different groups within the same column having different superscripts are significantly different $(P \leq$ $0.05)$.

Table (2): Mean values of tyramine levels in the examined samples of canned fish ( $\mathrm{mg} / \mathrm{kg}$ )

\begin{tabular}{|c|c|c|c|c|c|c|c|}
\hline \multirow{2}{*}{ Product } & \multirow{2}{*}{ No } & \multicolumn{3}{|c|}{ Tuna } & \multicolumn{3}{|c|}{ mackerel } \\
\hline & & Min & $\max$ & Mean $\pm \mathrm{SE}^{*}$ & Min & $\max$ & $\mathrm{Mean} \pm \mathrm{SE}^{*}$ \\
\hline Local A & 15 & 0.14 & 0.7 & $0.36 \pm 0.040$ & 0.3 & 0.8 & $0.556 \pm 0.040$ \\
\hline Local B & 10 & 0.03 & 0.4 & $0.141 \pm 0.38$ & 0.1 & 0.25 & $0.174 \pm .0 .015$ \\
\hline Total & 25 & 0.03 & 0.7 & $0.274 \pm 0.035$ & 0.05 & 0.8 & $0.393 \pm 0.0485$ \\
\hline Imported A & 15 & 0.15 & 0.35 & $0.242 \pm 0.016$ & 0.2 & 1 & $0.497 \pm 0.058$ \\
\hline Imported B & 10 & 0.05 & 0.14 & $0.099 \pm 0.009$ & 0.05 & 0.3 & $0.148 \pm 0.026$ \\
\hline Total & 25 & 0.05 & 0.35 & $0.184 \pm 0.177$ & 0.1 & 1 & $0.368 \pm 0.047$ \\
\hline
\end{tabular}

*Means of different groups within the same column having different superscripts are significantly different $(P \leq$ $0.05)$. 
Table (3): Mean values of putrescine levels in the examined samples of canned fish $(\mathrm{mg} / \mathrm{kg})$ :

\begin{tabular}{|c|c|c|c|c|c|c|c|}
\hline \multirow{2}{*}{ Product } & \multirow{2}{*}{ No } & \multicolumn{3}{|c|}{ Tuna } & \multicolumn{3}{|c|}{ mackerel } \\
\hline & & Min & $\max$ & Mean $\pm \mathrm{SE}^{*}$ & Min & $\max$ & Mean \pm SE* \\
\hline Local A & 15 & 1.5 & 3 & $2.237 \pm 0.119$ & 1.8 & 3.5 & $2.4 \pm 0.119$ \\
\hline Local B & 10 & 1.2 & 1.8 & $1.41 \pm 0.057$ & 1.5 & 1.9 & $1.65 \pm 0.0453$ \\
\hline Total & 25 & 1.2 & 3 & $1.884 \pm 0.181$ & 1.5 & 3.5 & $2.1 \pm 0.104$ \\
\hline Imported A & 15 & 1.6 & 2.5 & $1.96 \pm 0.68$ & 1.6 & 3.1 & $2.237 \pm 0.126$ \\
\hline Imported B & 10 & 1 & 1.6 & $1.36 \pm 0.067$ & 1.2 & 1.6 & $1.38 \pm 0.0553$ \\
\hline Total & 25 & 1 & 2.5 & $1.72 \pm 0.076$ & 1.2 & 3.1 & $1.894 \pm .0 .115$ \\
\hline
\end{tabular}

*Means of different groups within the same column having different superscripts are significantly different $(P \leq$ $0.05)$.

Table (4): Acceptability of the examined canned fish samples for biogenic amines according to EOS (2005)

\begin{tabular}{lcccccc}
\hline & \multicolumn{7}{c}{ Acceptable Samples } \\
Product & Histamine & Tyramine & Putrescine \\
& NO. & $\%$ & NO. & $\%$ & NO. & $\%$ \\
\hline Local Tuna A & 15 & 100 & 15 & 100 & 15 & 100 \\
Local Tuna B & 10 & 100 & 10 & 100 & 10 & 100 \\
Imported Tuna A & 15 & 100 & 15 & 100 & 15 & 100 \\
Imported Tuna B & 10 & 100 & 10 & 100 & 10 & 100 \\
Local Mackerel A & 12 & 92 & 15 & 100 & 15 & 100 \\
Local Mackerel B & 10 & 100 & 10 & 100 & 10 & 100 \\
Imported Mackerel A & 15 & 100 & 15 & 100 & 15 & 100 \\
Imported Mackerel B & 10 & 100 & 10 & 100 & 10 & 100
\end{tabular}

Permissible limits according to EOS 2005 (histamine 50mg/kg, tyramine 10mg/kg and putrescine 20mg/kg).

\section{DISCUSSION}

From results in Table 1, histamine level was high in local mackerel followed by imported mackerel then local tuna and imported tuna, which may be attributed to that mackerel have large amounts of free histidine in their muscular tissue. It can serve as a substrate for bacterial histidine decarboxylase, which converts histidine to histamine and results in the accumulation of histamine in the fish muscles. Upon consumption of the affected food, a short incubation period is followed by the onset of symptoms (Taylor, 1986) and use of poor quality fish for canning (Allen et al., 2004). All canned tuna and mackerel samples contain histamine within permissible limits according to EOS (2005) $50 \mathrm{mg} / \mathrm{kg}$ But about $8 \%$ of mackerel samples exceed maximum permissible limits $50 \mathrm{mg} / \mathrm{kg}$. The present results come in agreement to Sabater et al. (1994) (30.9) and higher than that recorded by Hanan (2003) (5.7), Park (2010) (1.4), Amal (2012) (3) and Poulose et al. (2013) (3.1) and lower than recorded by Karmi (2014) (55-237). Actually, the presence of histamine in all Tuna and Mackerel samples is of great interest for two reasons: firstly, for their role as possible quality indicators and secondly, for their toxicological aspects in the sense that high levels of dietary histamine can be toxic for certain consumers. Cooling and good handling practices can avoid histamine formation. From results in Table 2 we found 
that tyramine level high in local mackerel followed by imported mackerel then local tuna and imported tuna which may be attributed to presence of higher temperature which favored proteolytic and decarboxylase activities of microorganisms resulting in increased tyramine concentrations in these food articles containing higher contents of tyrosine (Saccani et al., 2005). All tuna and mackerel samples were acceptable for tyramine according to (EOS, 2005) $10 \mathrm{mg} / \mathrm{kg}$. The present results were lower than that recorded by Park (2010) (3.2 and 4.7), Amal (2012) (2) and Karmi (2014) (201.5 and 99.5). Generally, tyramine is produced in any food item as result of decarboxylation of the amino acid tyrosine. From results in Table 3, putrescine level was high in local mackerel followed by imported mackerel then local tuna and imported tuna, which may be, attributed to presence of bacteria that decarboxylate ornithine to putrescine, poor hygienic levels of manufacturing process, using raw materials of poor quality (Kim et al., 2001). All tuna and mackerel samples were acceptable for putrescine according to (EOS, 2005) $20 \mathrm{mg} / \mathrm{kg}$. Generally, putrescine is produced in any food item as result of decarboxylation of the amino acid ornithine. The present results come with agreement with that recorded by Park et al. (2010) (1.8 and 2.3)and Amal (2012) (1).

Finally, we concluded that all samples of both canned tuna and mackerel were acceptable for histamine, tyramine and putrescine except $8 \%$ of canned mackerel exceeded permissible limits for histamine according to Egyptian Organization of Standardization (EOS, 2005).

\section{REFERENCES}

Allen, G., Green, D., Bolton, G., Jaykus, L., Cope, G. 2004. Detection and identification of histamine producing bacteria associated with harvesting and primary processing of Tuna in
North Carolina. J. Food Protect., 67: 79-81.

Amal, A.R., Hamed, A. 2012. Estimation of biogenic amines in salted - fermented fish and some fish products in Cairo Markets with special references to its storage. Report and Opinion, 4:6.

Andreson, A.K. 2008. Biogenic and volatile amine -related qualities of 3 popular fish sold at Kuwait fish markets. J. Food Chem., 107(2):761767.

Byran, F.L.1980. Epidemiology of food born diseases transmitted by fish, shellfish and marine crustaceans in the United States, 1970-1978. Food Protect. J., 43(11):832-891.

Egyptian Organization for Standardization and Quality" E.O.S."2005. Detection of poisons and control. Report No.1796.

Hanan, G.S. 2003. Some harmful agents in canned fish M.V.Sc. Fac. Vet. Med. Zag. Univ. Egypt.

Hannah, P., Glover, V., Sandler, M. 1988. Tyramine in wine and beer. The Lancet, 1(8590):879.

Karmi, M. 2014. Determination of Histamine and Tyramine Levels in Canned Salted Fish by Using HPLC. Global Veterinaria, 12(2):264-269.

Kim, S.H., Field, K.G., Chang, D.S., Wei, C.I., An, H. 2001. Identification of bacteria crucial to histamine accumulation in pacific mackerel during storage. J. Food Protect., 64:1556-1564.

Lorenzo, J.M., Martinez, S., Franco, I., Carballo J. 2007. Biogenic amine content during the manufacture of dry-cured lac 'on, a Spanish traditional meat product: Effect of some additives. Meat Sci., 77(2):287293.

Mietz and Karmas, E. 1977. Chemical quality index for canned tuna as determined by high pressure liquid chromatography. J. Food Sci., 42: 155-158. 
Park, J.S., Lee, C.H., Kwon, E.Y., Lee, H.J., Kim, J.Y., Kim S.H. 2010. Monitoring volatile and non-volatile amines in fish and fish products consumed in Korea. Food Control J., 21:1219-1226.

Poulose, Y., Al-Zidjali, M., Al-Zidjali, A., Al-Busaidi, M, Al-Waili, A., AlMazrooei, N., Al-Habsi, S. 2013. Histamine level in commercially important fresh and processed fish of Oman with reference to international standards. J. Food Chem., 140(4):777-783.

Sabater, L., Emilio, I., Jerez, R., Jose, J., Sagues, R., Artur, X., Ventura, M., Teresa, M.A. (1994). Bacteriological quality of tuna fish (Thunnus, thynnus) destined for canning: Effect of tuna handling on presence of histidine decarboxylase bacteria and histamine level. J. Food Protect., 57(4):318-323.

Saccani, G.; Tanzi, E.; Pastore, P.; Cavalli, S. and Rey, M. 2005. Determination of biogenic amines in fresh and processed meat by suppressed ion chromatography - mass spectrometry using a cation - exchange column. J. Chromatogr. A., 1082:43-50.

Silva, M.T., Sabaini, P.S., Evangelista, P.W., Gloria, M.B. 2011. Occurrence of histamine in Brazilian fresh and canned tuna. Food Control J., 22:323327.

SPSS.14, 2006. Statistical Package for social science, SPSS for windows release 14.0.0, 12 June 2006 standard version, copyright spss Inc., (1989:2006). All Rights Reserved, copy right SPSS Inc.

Taylor, S.L. 1986. Histamine food poisoning: Toxicology and clinical aspects. Critical Reviews in Toxicology, 17(2):91-128.

Tsai, Y.H., Kung, H.F., Lee, T.M., Chen, H.C., Chou, S.S., Wei, C.I., Hwang, D.F. 2005. Determination of histamine in canned mackerel implicated in a food borne poisoning. Food Control, J., 16:579-585. 